結果か得られていない，それは頭頸部癌は固形癌であ り, in vitroに扔ける均一な単層培責細胞とは腫瑒生 物学的に異なるためである。そこで我々は，上ト喉頭 癌由来 HEP-2 扁平上皮癌細胞株を用いて, 多細胞久 フェロイド Multicellular Tumor Spheroids (MTS) を作製している.MTSは，3次元構造を有す球形の， 細胞同期の異なった細胞膜であり, 单層培養細胞と比 べ，より蹊床に近い in vitro の実娩系であると考えら 扟る。我々は，このMTSを用いて，固形癌に対する化 学療法の効果向上を図るために「薬剤の腫湟塊への樑 達性」に着目し検討している。今回我々はアドリアマ イシン $(\mathrm{ADR})$ とシスプラチン (CDDP) を併用し, MTSに扔ける薬剂の腫凘塊への深達性について検討 したので報告する。

一般に ADR は CDDPに比心, 睡怚塊への深達性の 悪いことが認められている。そこでMTSにおいて， ADR を単独に作用させた場合と, ADR と CDDP を併 用して作用させた場合の clonogenic assayによる survival fraction 比較すると, 後者に殺細胞効果の 増強がみられた。また，CDDPを作用させるにあたり，
その時間依存性と濃度依存性について検討すると，そ の結果 CDDP は ADR の 1 時間前に作用させた時が 最も殺細胞効果があり,また CDDP の濃度は, 単層培 養細胞に対しては non-toxic doseでもMTSに対し てはADR との併用効果がみられることがわかった。 このメカニズムを検討寸るために, MTS の病理切片 を作製し螢光顕微鏡で観察すると, ADR 单独に比べ CDDPで前処理したMTSにおいてよりADRが MTSの内層の細胞人到達していることが扣かた。

以上より，MTSにおけるADRの効果については， CDDPを前処理させることにより，ADRのMTSに 対する哚達性が向上し, 殺細胞効果が増強することが 示唆された。質問 熊澤博文(県立宮古)。深達性 の定義としてこの実駼でどのくらいの強さを想定して いるか。応答 使用しているMTSの直系山 $700 \mu \mathrm{m} \sim 1 \mathrm{~mm}$ であり，MTS の表層から 100〜150 $\mu \mathrm{m}$ の viable cell からさらにその内層の細胞層まで検討 している.MTSの腫瘍内深達性とは，いわ功る固型癌 の cord structureである $200-300 \mu \mathrm{m}$ を考えている.

\title{
242. 上䪽癌由来樹立細胞に対する化学予防剤の影響
}

\author{
井上 功・伊藤 尚 高崎智彦・杉田邦洋・山本鞙三 高橋宏明 (人阪医大)
}

目的 我々は第91回本学会で4-nitroquinoline 1oxide 誘発ラット舌癌に対してビタミンA，七レニウ ム，BHT が chemopreventiveに作用することを報告 した，その機序として発癌物質の代謝過程への作用か 考えられたが,さらに癌細胞と前癌状態の細胞に対す る增殖抑制作用の存在が示唆された。今回, この点を 明らかにする目的で上記薬剤の上顎癌由来培養細胞の 增殖能，細胞回転に対する影響を検討した。

方法 細胞：上影癌由来培養細胞 (石田株)，化学予 防刘：ビタミンA (vitamin A acetate), セレニウム (sodium selenite), BHT (butylated hydroxytoluene) 1. 簡易毒性試験：96ウ土ルマイクロプレート上で各 薬戍の希䣋系列を作製し，各ウょルに細胞を滴下した。 3日後, クリスタル紫染色を施し自動比色計で各り」 几の吸光度を測定し各薬片が作用するおおよその濃度 を調ベた。2.コロニー形成法：培養 dishに細胞を接 種し72時間培傼後, 各濃度の薬剂を添剤した.9日後, ギムザ染色を施し，コロニー数を肉眼的に算定し，対 照群に対する割合を細胞生存率（\%)として薬剤別に 比較した。 3. Cell kinetics： dish に細胞を接種し72
時間培責後 $50 \%$ 細胞增殖抑制濃度の各薬刘を添加し 1，3，5，7 日間培養した。各 dishの細胞を $\mathrm{BrdU}$ (bromodeoxyuridine) と接触させた後, 抗 BrdU 抗 体-FITC 染色,さらに Propidium Iodide で核酸染色 を施し, flow cytometry にてS 期陽性細胞率と細胞内 DNA 童を測定した。

結果および考察 簡易毒性試験にて $50 \%$ 阻害濃度は セレニウム: $0.54 \mu \mathrm{g} / \mathrm{ml}$, ビタミン A $: 52 \mu \mathrm{g} / \mathrm{ml}$, BHT: $74 \mu \mathrm{g} / \mathrm{ml}$ であった。コロニ一形成法にて $50 \%$ 細胞增殖抑制濃度はセレニウム: $3.6 \mu \mathrm{g} / \mathrm{ml}$, ビタミン $\mathrm{A}: 28 \mu \mathrm{g} / \mathrm{ml}, \mathrm{BHT}: 74 \mu \mathrm{g} / \mathrm{ml}$ であった。この濃度で の細胞周期への影響を調べた結果，セレニウムは $\mathrm{S}$ 期 細胞が増加し, DNA 合成阻害作用が示唆された。ビ夕 ミン $\mathrm{A}$ は $\mathrm{G}_{0} / \mathrm{G}_{1}$ 期細胞が增加し， $\mathrm{G}_{1}$ 期でのブロック 機構が考えられた。BHTは1日目には $\mathrm{G}_{2}+\mathrm{M}$ 期細胞 の増加を示す $3 \sim 7$ 日目には $\mathrm{G}_{0} / \mathrm{G}_{1}$ 期細胞が增加し， より複雑な機構の存在が考えられた。以上よりビタミ ンA，七レニウム、BHTは細胞動態的に異なる機序に 基づく増殖抑制作用を有することが確認された。 